\title{
Influence of pre and postnatal energy restriction on the productive performance of ewes and lambs ${ }^{1}$
}

\author{
Filipe Alexandre Boscaro de Castro ${ }^{2}$, Edson Luis de Azambuja Ribeiro ${ }^{3}$, Ivone Yurika \\ Mizubuti ${ }^{3}$, Leandro das Dores Ferreira da Silva ${ }^{3}$, Marco Aurélio Alves de Freitas Barbosa ${ }^{3}$, \\ Cícero Leandro de Sousa ${ }^{2}$, Fernando Henrique Pereira de Paiva ${ }^{2}$, Natália Albieri Koritiaki ${ }^{2}$
}

\footnotetext{
1 Project supported by CNPq and Fundação Araucária de Apoio ao Desenvolvimento Científico e Tecnológico do Paraná.

2 Programa de Pós-Graduação em Ciência Animal da Universidade Estadual de Londrina - UEL.

${ }^{3}$ Departamento de Zootecnia da Universidade Estadual de Londrina - UEL.
}

\begin{abstract}
The objective of this study was to evaluate the influence of feeding energy levels during the last third of gestation and lactation on performance of ewes and lambs up to weaning. The experiment was carried out in the sheep raising sector of Universidade Estadual de Londrina (UEL), from August to December of 2007. Thirty-two adult lambs with 105 days of gestation, average live weight of $57.55 \mathrm{~kg}$ and average body condition scores of 3.42 were used in the beginning of the experiment. The animals were confined in collective pens, distributed randomly in three treatments: $2.4 ; 2.2$ and 2.0 Mcal of metabolizable energy (ME)/kg of dry matter (DM). Feed supply was ad libitum during the last third of gestation and lactation. Weaning occurred at 70 days. Body weight, body condition score and milk production of ewes and body weight of the lambs were analyzed. There were no significant differences for body weight and body condition of ewes at lambing; however, the level of 2.4 Mcal enabled better results for those characteristics at weaning and higher gain in weight and body condition scoring during the experiment. Severe energetic restriction (2.0 Mcal ME/kg DM) determined lower average daily milk production. Lambs from levels 2.4 and 2.2 presented similar weights in all measurements and were superior to those in level 2.0. Lambs from level 2.4 presented higher average weight gain from birth to weaning. The energetic restriction upon lambs at the end of gestation and during lactation limits the performance of ewes and lambs up to weaning.
\end{abstract}

Key Words: body condition, milk production, mortality, sheep, weight gain

\section{Introduction}

Ewes go through periods of different nutritional needs throughout the year, according to their physiological state, and one of the most critical is the last part of their gestational period (NRC, 2007). The improvement of the nutritional level of ewes in this period, besides increasing the viability of lambs, reduces the occurrence of dystocia, synchronizes milk letdown with lambing and minimizes sheep mortality rate by pregnancy toxemia (Minola \& Goyenechea, sd).

During the period between conception and lambing, anabolic processes such as placental, fetal and mammary tissue development are supported by the supply of nutrients. Any deficiency in the supply of nutrients during these activities may compromise the survival and wellbeing of mother and offspring (Mellor, 1987).

According to Minola \& Goyenechea (sd), during the first two thirds of the gestational period, the differentiation process of fetus tissues and organs take place, and, in the final third, a development process responsible for
$70 \%$ of its weight at birth occurs, increasing the demand of sheep energy by $60 \%$ in relation to the initial period (NRC, 2007).

Lamb mortality rate at delivery and in the first hours after delivery is closely related to hunger and cold (Souza et al., 2009). The main causes of lamb death from starvation are related to maternal feeding, pre and postnatal (Avendaño \& Imbarach, 2002; Souza et al., 2009), and with the behavior of the mother and the offspring (Minola \& Goyenechea, sd).

Intrauterine nutritional restriction may compromise lamb productive development, even with ad libitum feeding during suckling. This is a reflection of their low weight at birth (Geraseev et al., 2006).

Avendaño \& Imbarach (2002) concluded that feed supplementation to ewes during peripartum leads to better body conditions at lambing and during the first fifteen days of lactation. Reduction of nutrient intake in lactating ewes results in great losses in body reserves and, consequently, decrease in reproductive performance (Boucinhas et al., 2006). 
The objective of this study was to evaluate the influence of energy levels in the feeding of ewes during the last third of their gestational period and during lactation on their performance and that of their lambs, until weaning.

\section{Material and Methods}

The experiment was conducted at the sheep raising sector of Universidade Estadual de Londrina, from August to December 2007. The School Farm is located in the municipality of Londrina (Lat. S. $23^{\circ} 20^{\prime} 10^{\prime \prime}$ and Long. W. $\left.51^{\circ} 09^{\prime} 15^{\prime \prime}\right)$, with 610 meters of altitude, average annual temperature of $20.6^{\circ} \mathrm{C}$, average annual rainfall of $1,439.8$ $\mathrm{mm}$, reaching its maximum in January (201.4 mm average) and its minimum in June (56.5 mm average) (Maack, 1981).

Sheep were kept in collective, semi-covered pens, with a concrete floor, with an area of approximately $4.5 \mathrm{~m}^{2}$ per sheep. At lambing, the animals were taken to a sheepfold, with slatted floor and individual stalls of $1.3 \times 2 \mathrm{~m}$.

The experiment used 32 adult ewes (4, 6 and 8 teeth) at $105 \pm 16.95$ days into gestation, average body weight of $57.55 \pm 11.01 \mathrm{~kg}$ and average body condition score of $3.42 \pm 0.62$ at the beginning of the experiment. Body condition score was determined by palpating the vertebral column after the last rib, above the kidney, according to the methodology described by Osório \& Osório (2005), with values from 1 to 5 , where 1 corresponds to extremely thin animals and 5 to extremely fat animals. Diets with three levels of metabolizable energy (ME; 2.4; 2.2 and 2.0 Mcal ME/kg dry matter (DM)) were evaluated and randomly distributed to the animals. There were limits to casualization due to the sheep genetic group (wool sheep = half-breed Hampshire Down and half-breed Ile de France; hair sheep = Santa Inês).

Sheep mating took place during the pre-experimental period, from March to April 2007, using males from the Santa Inês breed. Identification of mated ewes was carried out by using a marking paint technique on the sternum ventral region of the ram body, with daily inspections of the herd.

Deliveries occurred in the months of August and September. After lambing, ewes were kept in individual stalls with their lamb(s), for three days, and then taken back to the collective pens. Newborn lambs remained with their mothers until weaning, at 70 days of age. Lamb management procedures such as navel disinfection, weighing and marking were done after the newborns had been cleaned by their mothers and suckled the colostrum.

Parasite prophylaxis was carried out in the beginning of the experiment with the application of anthelmintic drugs in animals with lab results above 500 eggs per gram of feces (EPG). The Gordon and Whitlock method, described by Hoffmann (1987), was used to diagnose EPG.

Experimental diets were formulated after the chemical analysis of the feedstuff and consisted of sorghum silage and concentrate diet, made of ground corn, soybean meal, cottonseed meal, urea, soybean oil, and calcitic calcareum at different proportions, according to the energy level (Table 1). Diets were isoprotein and with different energy levels: 2.4; 2.2 and 2.0 Mcal of ME/kg of DM (Table 2). Metabolizable energy was calculated following the feed energy values, according to Campos (1995). The 2.4 level meets the nutritional energy requirements of $60 \mathrm{~kg}$ ewes at the last third of the gestational period (NRC, 1985; NRC, 2007); and 2.2 and 2.0 correspond to the energy restrictions.

The animals were fed ad libitum twice a day, at 8 a.m. and 5 p.m. The amount of feed was adjusted daily so as to leave a residue of approximately $20 \%$ of the total offered. Ewes were subjected to experimental diets during the last third of their gestational period and during lactation. Mineral supplement and water were provided ad libitum in appropriate troughs.

Ewes and lambs were weighed weekly to follow weight evolution and daily weight gain. Weighing took place

Table 1 - Feed composition of experimental diets (g/kg of DM)

\begin{tabular}{lccc}
\hline Ingredients & \multicolumn{3}{c}{$\begin{array}{c}\text { Level of metabolizable } \\
\text { energy }\end{array}$} \\
\cline { 2 - 4 } & 2.4 & 2.2 & 2.0 \\
\hline Sorghum silage & 600 & 800 & 960 \\
Ground corn & 280 & 120 & 0 \\
Soybean meal & 65 & 55 & 25 \\
Cottonseed meal & 26 & 15 & 0 \\
Urea & 0 & 0 & 10 \\
Soybean oil & 26 & 8 & 0 \\
Calcitic calcareum & 3 & 2 & 5 \\
\hline
\end{tabular}

DM - dry matter.

Table 2 - Chemical composition of experimental diets

\begin{tabular}{|c|c|c|c|}
\hline \multirow[t]{2}{*}{ Nutrients } & \multicolumn{3}{|c|}{$\begin{array}{l}\text { Level of metabolizable } \\
\text { energy (Mcal } / \mathrm{kg} \text { of } \mathrm{DM} \text { ) }\end{array}$} \\
\hline & 2.4 & 2.2 & 2.0 \\
\hline $\mathrm{DM}$ ( $\mathrm{g} / \mathrm{kg}$ as fed) & 36.63 & 31.42 & 28.36 \\
\hline $\mathrm{OM}(\mathrm{g} / \mathrm{kg}$ of $\mathrm{DM})$ & 936.6 & 928.5 & 926.3 \\
\hline $\mathrm{CP}(\mathrm{g} / \mathrm{kg}$ of $\mathrm{DM})$ & 112.7 & 111.3 & 114.0 \\
\hline $\mathrm{EE}(\mathrm{g} / \mathrm{kg}$ of $\mathrm{DM})$ & 42.1 & 28.7 & 17.9 \\
\hline MM $(\mathrm{g} / \mathrm{kg}$ of $\mathrm{DM})$ & 63.4 & 71.5 & 73.7 \\
\hline NDF $(g / k g$ of $D M)$ & 460.0 & 516.0 & 662.0 \\
\hline $\mathrm{ADF}(\mathrm{g} / \mathrm{kg}$ of $\mathrm{DM})$ & 291.0 & 346.0 & 429.0 \\
\hline TDN $(g / k g \text { of } D M)^{1}$ & 700.0 & 638.0 & 546.0 \\
\hline
\end{tabular}

${ }^{1}$ Estimated from feed compositions according to equation proposed by Kearl (1982).

DM - dry matter; OM - organic matter; CP - crude protein; EE - ether extract MM - mineral matter; NDF - neutral detergent fiber; ADF - acid detergent fiber; TDN - total digestible nutrients. 
always in the morning, at the same time, before the supply of feed. Body condition scores of the ewes were measured during weighing.

Milk production at 9, 15, 29, 43 and 57 days of lactation was estimated through manual milking after the lambs were separated from their mothers for 4 hours, according to the methodology described by Podleskis et al. (2005). During evaluation days, the lambs were closed in stalls in the sheepfold at 6:30 a.m., and then reunited with their mothers at 8 a.m., for 30 minutes, allowing them to suckle until the udder was completely emptied. Then, the lambs were led to their stalls where they stayed until 12:30 p.m., when the ewes were then milked. Ewes had the right half of the udder milked, and the amount of milk collected was multiplied by two to adjust production per animal, and, based on the lamb suckling restriction time, the production was adjusted to 24 hours.

All chemical analyses were carried out at the Animal Nutrition Laboratory of Universidade Estadual de Londrina. Dry matter (DM), mineral matter (MM), organic matter $(\mathrm{OM})$, crude protein (CP) ethereal extract (EE), neutral detergent fiber (NDF) and acid detergent fiber (ADF) were quantified according to Silva \& Queiroz (2002).

Data were submitted to an analysis of variance, using the GLM procedure of the statistical software package SAS (version 8.2). The statistical model considered the following independent variables: treatments $(2.4 ; 2.2$ and 2.0 Mcal of ME/kg of DM), genetic group (wool and hair sheep) and type of lambing (single or twins). Interactions between independent variables were not included in the discussion for lack of significance $(\mathrm{P}>0.05)$. Data on the characteristics affected by diet energy levels $(\mathrm{P}<0.05)$ were also submitted to a regression analysis.

\section{Results and Discussion}

Although weights at lambing were not different ( $\mathrm{P}>0.05$ ), the energy level of $2.4 \mathrm{Mcal} / \mathrm{kg} \mathrm{DM}$ was the only one that contributed to ewe weight gain from the beginning of the experimental period until lambing (Table 3). Both diets with energy restriction determined weight loss during the mentioned period. Likewise, Scheaffer et al. (2004) verified that energy restriction during the last third of gestation affected ewe weight averages, determining lower weights at lambing.

Ewes had similar weight averages for the different energy levels until 15 days after lambing, although this last weighing showed that animals from the 2.4 level had an average of nearly $8 \mathrm{~kg}$ more than the animals from the $2.0 \mathrm{Mcal} / \mathrm{kg}$ DM level. A significant difference $(\mathrm{P}<0.05)$ was found between energy levels from 29 days after lambing until weaning, where ewes that were submitted to a diet with 2.4 Mcal of ME/kg of DM showed higher weight average than ewes that had been submitted to energy restriction (2.2 and 2.0 Mcal of ME/kg of DM). The regression analysis showed a linear reduction in weight as the energy levels decreased (Table 3).

A limitation in ewes performance due to less energy support was found, with greater weight loss for level 2.0 Mcal ME/kg DM, during the experimental period $(\mathrm{P}<0.05)$. Ewe weight variation was practically not observed, from the beginning to the end of the experiment, for levels 2.4 and 2.2 .

Genetic group (wool and hair sheep) and type of lambing (single or twins) had no effect on ewe weights during the experiment, except for the initial weight of ewes with a raising twin, which was greater than those of ewes who were

Table 3 - Weight averages of ewes (in kg) at the beginning of the experiment (BW), at lambing (LW), 9 (W9), 15 (W15), 29 (W29), 43 (W43), 57 days after lambing (W57), at weaning (WW) and average daily gain (ADG) at different energy levels

\begin{tabular}{|c|c|c|c|c|c|c|}
\hline Variable & \multicolumn{3}{|c|}{ Level of metabolizable energy (Mcal/kg of DM) } & Regression & $\mathrm{R}^{2}$ & CV (\%) \\
\hline BW & 59.50 & 57.81 & 60.89 & $\hat{y}=59.40$ & - & 19.5 \\
\hline LW & 60.34 & 55.58 & 55.22 & $\hat{y}=57.05$ & - & 15.4 \\
\hline W9 & 58.17 & 52.99 & 52.33 & $\hat{\mathrm{y}}=54.50$ & - & 15.7 \\
\hline W 15 & 58.21 & 51.53 & 50.32 & $\hat{y}=53.35$ & - & 15.5 \\
\hline W5 5 & 61.81 & 52.28 & 47.01 & $\hat{y}=37.95 x-30.23$ & 0.37 & 15.5 \\
\hline WW & 61.19 & 53.11 & 47.42 & $\hat{y}=35.48 x-24.69$ & 0.36 & 14.8 \\
\hline ADG & 0.02 & -0.04 & -0.12 & $\hat{y}=0.30 x-0.70$ & 0.34 & 220.2 \\
\hline
\end{tabular}

$\mathrm{n}$ - number of animals; $\mathrm{R}^{2}$ - coefficient of determination; CV - coefficient of variation. 
carrying a single lamb only (Table 4). This was probably due to the greater weight for the two fetuses, since no significant difference between ewe weights at lambing was observed.

Ewes that underwent single lambing lost less weight $(\mathrm{P}<0.05)$ during the experimental period than those that had undergone twin lambing. Supposedly, this was due to the greater need for nutrients to meet the demands of ewes raising twins.

One case of cervicovaginal prolapse at the end of a twin gestation of an ewe from the $2.0 \mathrm{Mcal} \mathrm{ME} / \mathrm{kg} \mathrm{DM}$ diet group was observed. This same ewe, later on, developed pregnancy toxemia, thus being excluded from the experiment and treated with intravenous glucose. A ewe from the same experimental group died 35 days after lambing, showing signs of malnutrition and weakness. Therefore, $18 \%$ of the ewes from treatment 2.0 were lost possibly due to diet-related causes. Villas Boas (1990) considers badly managed herds those with an annual ewe loss of over $5 \%$.

There was a difference $(\mathrm{P}<0.05)$ in DM intake (Table 5), when expressed in kg per animal/day, where animals from the 2.4 Mcal ME/kg DM level consumed higher amounts. This was probably due to the lower NDF content in the corresponding experimental diet and to the higher weight averages presented by the ewes submitted to the referred energy level. However, when DM intake was expressed as a percentage of live weight and as grams per unit of metabolic size, no significant differences were found $(\mathrm{P}>0.05)$.
All consumption results, expressed in the different forms, are according to the NRC $(1985 ; 2007)$ and show that animals with 2.2 and 2.0 Mcal ME/kg DM levels did not compensate a lower energy content of the diets by increasing the DM intake.

Body condition scores for the different energy levels follow the same weight trend, presenting a positive correlation $(r=0.68 ; 0.62 ; 0.50 ; 0.72 ; 0.77 ; 0.78 ; 0.75$ for lambing, 9, 15, 29, 43, 57 days postpartum and weaning, respectively) between these two variables (Table 6).

According to Caldeira \& Vaz Portugal (1998), body condition score measurement is a more efficient method than body weight when comparing animals of different genetic groups.

Ewes which were fed $2.4 \mathrm{Mcal} / \mathrm{kg}$ of DM showed better scores $(\mathrm{P}<0.05)$; however, this difference was observed 9 days after lambing and was almost significant at lambing $(P=0.0555)$. The study of the regressions showed that as the energy level decreased, there was a linear reduction in body condition scores (Table 6). Moura Filho et al. (2005), observed higher body scores at lambing for ewes supplemented with concentrate (2.79) during the last third of gestation in relation to a group of ewes without supplementation (2.26). However, these scores were inferior to those measured in the present experiment $(3.54 ; 3.15$ and 2.95 for the metabolizable energy levels of $2.4 ; 2.2$ and $2.0 \mathrm{Mcal} / \mathrm{kg}$ of DM, respectively). Similarly to weight,

Table 4 - Weight averages of ewes (in kg) for genetic group and type of lambing at the beginning of the experiment (BW), at lambing (LW), 9 (W9), 15 (W15), 29 (W29), 43 (W43), 57 days after lambing (W57), at weaning (WW) and average daily gain (ADG)

\begin{tabular}{|c|c|c|c|c|c|c|c|}
\hline & \multicolumn{2}{|c|}{ Genetic group } & \multirow[b]{2}{*}{$\operatorname{Pr}>\mathrm{F}$} & \multicolumn{2}{|c|}{ Type of lambing } & \multirow[b]{2}{*}{$\operatorname{Pr}>F$} & \multirow[b]{2}{*}{ CV (\%) } \\
\hline & Wool $(n=12)$ & Hair $(n=18)$ & & Single $(n=19)$ & Twins $(\mathrm{n}=11)$ & & \\
\hline BW & 60.63 & 58.17 & 0.5301 & 53.58 & 65.22 & 0.0075 & 17.8 \\
\hline LW & 60.63 & 56.84 & 0.9042 & 54.42 & 59.67 & 0.1362 & 15.5 \\
\hline W9 & 54.63 & 54.36 & 0.9319 & 51.93 & 57.06 & 0.1362 & 15.8 \\
\hline W 15 & 53.32 & 53.39 & 0.9817 & 51.58 & 55.13 & 0.2916 & 15.9 \\
\hline W 29 & 53.72 & 52.35 & 0.6875 & 51.57 & 54.50 & 0.4067 & 16.8 \\
\hline W 43 & 54.03 & 52.51 & 0.6555 & 52.03 & 54.51 & 0.4835 & 16.7 \\
\hline W 57 & 54.84 & 52.56 & 0.4945 & 52.95 & 54.45 & 0.6613 & 16.1 \\
\hline W W & 55.09 & 52.72 & 0.4562 & 52.77 & 55.04 & 0.4877 & 15.4 \\
\hline $\mathrm{ADG}$ & -0.05 & -0.05 & 0.9724 & -0.01 & -0.09 & 0.0028 & 194.0 \\
\hline
\end{tabular}

$\mathrm{n}$ - number of animals; CV - coefficient of variation.

$\operatorname{Pr}>\mathrm{F}$ : probability of significance.

Table 5 - Dry matter (DM) intake per animal/day, as a percentage of live weight (LW) and per unit of metabolic size (g/LW ${ }^{0.75}$ ) for the different energy levels

\begin{tabular}{|c|c|c|c|c|c|c|}
\hline \multirow[t]{2}{*}{ Variable } & \multicolumn{3}{|c|}{ Level of metabolizable energy ( $\mathrm{Mcal} / \mathrm{kg}$ of $\mathrm{DM}$ ) } & \multirow[b]{2}{*}{ Regression } & \multirow[b]{2}{*}{$\mathrm{R}^{2}$} & \multirow[b]{2}{*}{ CV $(\%)$} \\
\hline & $2.4(n=11)$ & $2.2(\mathrm{n}=10)$ & $2.0(\mathrm{n}=9)$ & & & \\
\hline $\mathrm{kg} / \mathrm{animal}$ & 2.23 & 1.81 & 1.54 & $\hat{y}=1.713 x-1.910$ & 0.98 & 37.4 \\
\hline $\mathrm{g} / \mathrm{LW}^{0.75}$ & 103 & 90 & 84 & $\hat{y}=92.3$ & - & 37.9 \\
\hline
\end{tabular}

$\mathrm{n}$ - number of animals; $\mathrm{R}^{2}$ - coefficient of determination; CV - coefficient of variation; LW - live weight. 
level 2.4 was the only one that presented an increase in body condition score from the beginning of the experiment to lambing.

A difference in score variation $(\mathrm{P}<0.05)$ from the beginning to the end of the experiment was detected for the different levels, where ewes submitted to energy restriction (2.2 and 2.0 Mcal ME/kg of DM) showed negative variation, i.e., loss in body condition.

Ewes subjected to 2.4 Mcal ME/kg of DM had a body condition score of 3.77 at weaning, a value much higher than the 2.5 proposed by Susin (1996). The energy supply after the first month of lactation was above the $1.9 \mathrm{Mcal} \mathrm{ME} / \mathrm{kg} \mathrm{DM}$ required by the category (NRC, 2007), which led to an exaggerated increase in score during this period. These findings led us to assume that animals submitted to the energetic level abovementioned had enough body reserves to produce milk, so it was unnecessary to keep them on a high body condition during this productive phase, which could incur in economic losses for the producer and waste of nutrients. On the other hand, animals from 2.2 and 2.0 levels presented scores lower than 2.5 at the end of lactation, which could result in an extension of the postpartum anestrus and, consequently, in an increase in the production cycle period.

Ewes nursing twins showed, at the end of the considered period, a negative score variation greater $(\mathrm{P}<0.05)$ than those which had one lamb only (Table 7). This was due to the greater need for body reserves mobilization in that category as a result of the increase in nutritional demand.

For genetic group, wool sheep presented higher body score than the hair sheep in most measurements (Table 7). However, total score variation in the experimental period did not reflect this superiority, whose values were statistically similar $(\mathrm{P}>0.05)$ for both genetic groups.

In relation to milk production (Table 8), there was no statistical difference for most of the measuring days. However, in response to the energy level of $2.4 \mathrm{Mcal} \mathrm{ME} / \mathrm{kg} \mathrm{DM}$, animals from this group presented the greatest $(\mathrm{P}<0.05)$ average daily milk production.

Godfrey \& Dodson (2003), using feed supplementation from 14 days before lambing, concluded that prenatal

Table 6 - Average body condition score of ewes at the beginning of the experiment (BBCS), at lambing (LBCS), 9 (BCS9), 15 (BCS15), 29 (BCS29), 43 (BCS43), 57 days after lambing (BCS57), at weaning (WBCS) and total body score gain (BCSG) at different energy levels

\begin{tabular}{|c|c|c|c|c|c|c|}
\hline \multirow[t]{2}{*}{ Variable } & \multicolumn{3}{|c|}{ Level of metabolizable energy (Mcal/kg of DM) } & \multirow[b]{2}{*}{ Regression } & \multirow[b]{2}{*}{$\mathrm{R}^{2}$} & \multirow[b]{2}{*}{$\mathrm{CV}(\%)$} \\
\hline & $2.4(\mathrm{n}=11)$ & $2.2(\mathrm{n}=10)$ & $2.0(\mathrm{n}=9)$ & & & \\
\hline BBCS & 3.36 & 3.35 & 3.81 & $\hat{\mathrm{y}}=3.51$ & - & 17.8 \\
\hline LBCS & 3.54 & 3.15 & 2.95 & $\hat{\mathrm{y}}=3.21$ & - & 17.1 \\
\hline BCS9 & 3.08 & 2.45 & 2.49 & $\hat{\mathrm{y}}=1.569 \mathrm{x}-0.839$ & 0.16 & 22.7 \\
\hline BCS15 & 3.08 & 1.95 & 2.42 & $\hat{\mathrm{y}}=1.770 \mathrm{x}-1.435$ & 0.15 & 28.2 \\
\hline BCS29 & 3.41 & 1.95 & 1.87 & $\hat{\mathrm{y}} \quad 3.935 \mathrm{x}-6.275$ & 0.48 & 28.6 \\
\hline BCS43 & 3.66 & 1.95 & 1.62 & $\hat{y}=5.176 x-8.990$ & 0.65 & 26.2 \\
\hline BCS57 & 3.83 & 2.05 & 1.61 & $\hat{y}=5.646 x-9.963$ & 0.69 & 25.5 \\
\hline WBCS & 3.77 & 2.30 & 1.55 & $\hat{y}=5.621 x-9.857$ & 0.75 & 21.3 \\
\hline BCSG & 0.41 & -1.05 & -2.26 & $\hat{y}=6.586 x-15.409$ & 0.85 & 56.5 \\
\hline
\end{tabular}

DM - dry matter; $\mathrm{n}$ - number of animals; $\mathrm{R}^{2}$ - coefficient of determination; CV - coefficient of variation.

Table 7 - Average body condition score of ewes for genetic group and type of lambing, at the beginning of the treatment (BBCS), at lambing (LBCS), 9 (BCS9), 15 (BCS15), 29 (BCS29), 43 (BCS43), 57 days after lambing (BCS57), at weaning (WBCS) and total body score gain (BCSG)

\begin{tabular}{|c|c|c|c|c|c|c|c|}
\hline & \multicolumn{2}{|c|}{ Genetic group } & \multirow[b]{2}{*}{$\operatorname{Pr}>F$} & \multicolumn{2}{|c|}{ Type of lambing } & \multirow[b]{2}{*}{$\operatorname{Pr}>\mathrm{F}$} & \multirow[b]{2}{*}{ CV (\%) } \\
\hline & Wool $(\mathrm{n}=12)$ & Hair $(\mathrm{n}=18)$ & & Single $(n=19)$ & Twins $(\mathrm{n}=11)$ & & \\
\hline BBCS & 3.67 & 3.34 & 0.1524 & 3.35 & 3.66 & 0.1992 & 17.5 \\
\hline LBCS & 3.43 & 3.00 & 0.0399 & 3.13 & 3.29 & 0.4525 & 16.6 \\
\hline BCS9 & 2.93 & 2.42 & 0.0227 & 2.65 & 2.69 & 0.8416 & 21.2 \\
\hline BCS15 & 2.68 & 2.28 & 0.0827 & 2.56 & 2.41 & 0.5286 & 23.5 \\
\hline BCS29 & 2.71 & 2.12 & 0.0100 & 2.52 & 2.30 & 0.3067 & 23.0 \\
\hline BCS43 & 2.61 & 2.22 & 0.0667 & 2.51 & 2.32 & 0.3674 & 21.9 \\
\hline BCS57 & 2.74 & 2.25 & 0.0254 & 2.54 & 2.45 & 0.6461 & 21.4 \\
\hline WBCS & 2.75 & 2.32 & 0.0332 & 2.59 & 2.49 & 0.6262 & 19.5 \\
\hline BCSG & -0.92 & -1.02 & 0.5637 & -0.76 & -1.17 & 0.0254 & 52.3 \\
\hline
\end{tabular}

$\mathrm{n}$ - number of animals; CV - coefficient of variation; Pr>F: probability of significance. 
nutrition affects the initial milk production, leading to greater average daily production during the whole lactation period.

Average milk production correlated positively with average daily weight gain $(\mathrm{r}=0.58 ; \mathrm{P}<0.05)$ and with body condition score variation $(r=0.47 ; \mathrm{P}<0.05)$.

For the different genetic groups, hair sheep had superior performance $(\mathrm{P}<0.05)$ than that of the wool sheep in the general mean (Table 9). Ribeiro et al. (2007) observed that the Santa Inês breed has high milk production capacity and a prolonged lactation period, so it is recommended as a suitable breed for cheese production.

Ewes nursing single lambs presented higher average daily milk production $(\mathrm{P}<0.05)$, contrarily to the findings of Snowder \& Glimp (1991), Ramsey et al. (1998) and Cardellino \& Benson (2002), who observed higher productions for ewes nursing twins.

In this study, pregnant ewes carrying twins lost body weight from the beginning of the experiment to lambing. This was not observed in pregnant ewes carrying a single lamb, which also presented less body condition loss in the same period. This suggests that pregnant ewes carrying twins use their reserves prioritizing fetal growth.

Working with Ile de France and Hampshire Down ewes, Podleskis et al. (2005) did not find any significant difference for milk production, according to the number of lambs born and raised, and obtained higher production averages than those observed in the present study.
With regard to lambs, feed energy level resulted in statistical difference $(\mathrm{P}<0.05)$ in all weighing and in average daily weight gain (Table 10). Lambs from levels of 2.4 and 2.2 Mcal $/ \mathrm{kgDM}$ had weights statistically similar in all measurements, even though differences of 2.370, 3.280 and $4.580 \mathrm{~kg}$ for LW42, LW56 and LWW, respectively, were observed. Regression equations showed, for all weighing and for average daily gain, a linear reduction as the feed energy level provided decreased.

Average values of $5.79 \mathrm{~kg}$ (level 2.4) and $6.05 \mathrm{~kg}$ (level 2.2) for weight at birth are higher than the $4.63 \mathrm{~kg}$ observed by Geraseev (2006) in lambs of the Santa Inês breed and the $3.97 \mathrm{~kg}$ reported by Moura Filho (2005) in lambs from Ile de France and Hampshire Down ewes.

Silveira et al. (1992), Sibbald \& Davidson (1998) and Geraseev et al. (2006) reported reduced birth weight in lambs from ewes subjected to energy or protein restriction during the half and/or final period of gestation. Weight at birth for animals from groups 2.4 and 2.2 were similar and higher than those from group 2.0, which shows that animals subjected to severe feed restriction during the gestational period had their development affected.

Weight gain for lambs with no energy restriction $(0.300 \mathrm{~kg})$ was greater than that observed by Geraseev (2006) for the Santa Inês breed: $0.188 \mathrm{~kg} /$ day. However, this gain was similar to that observed by Carvalho et al. (1999), for $3 / 4$ Texel lambs $(0.316 \mathrm{~kg} /$ day) and lower than that reported

Table 8 - Daily milk production (MP) means (in mL) for the different energy levels

\begin{tabular}{|c|c|c|c|c|c|c|}
\hline \multirow[t]{2}{*}{ Variable } & \multicolumn{3}{|c|}{ Level of metabolizable energy (Mcal/kg of DM) } & \multirow[b]{2}{*}{ Regression } & \multirow[b]{2}{*}{$\mathrm{R}^{2}$} & \multirow[b]{2}{*}{$\mathrm{CV}(\%)$} \\
\hline & $2.4(\mathrm{n}=11)$ & $2.2(\mathrm{n}=10)$ & $2.0(\mathrm{n}=9)$ & & & \\
\hline MP 9 days & 606.69 & 231.60 & 221.97 & $\hat{y}=353.42$ & - & 117.6 \\
\hline MP 29 days & 65.56 & 511.00 & 166.57 & $\hat{y}=442.71$ & - & 86.4 \\
\hline MP 43 days & 776.06 & 641.10 & 197.78 & $\hat{y}=1309.48 x-2259.82$ & 0.18 & 74.6 \\
\hline
\end{tabular}

DM - dry matter; n: number of animals; $\mathrm{R}^{2}$ - coefficient of determination; CV - coefficient of variation; ADMP - average daily milk production.

Table 9 - Daily milk production (MP) means (mL) for genetic group and type of lambing

\begin{tabular}{|c|c|c|c|c|c|c|c|}
\hline & \multicolumn{2}{|c|}{ Genetic group } & \multirow[b]{2}{*}{$\operatorname{Pr}>F$} & \multicolumn{2}{|c|}{ Type of lambing } & \multirow[b]{2}{*}{$\mathrm{Pr}>\mathrm{F}$} & \multirow[b]{2}{*}{ CV (\%) } \\
\hline & Wool $(\mathrm{n}=12)$ & Hair $(\mathrm{n}=18)$ & & Single $(n=19)$ & Twins $(\mathrm{n}=11)$ & & \\
\hline MP9 days & 245.89 & 460.95 & 0.2456 & 477.36 & 229.48 & 0.1967 & 113.6 \\
\hline MP15 days & 242.80 & 653.59 & 0.1173 & 684.94 & 211.46 & 0.0823 & 116.1 \\
\hline MP29 days & 295.13 & 590.30 & 0.0852 & 593.73 & 291.70 & 0.0880 & 82.3 \\
\hline MP43 days & 318.20 & 758.43 & 0.0121 & 676.64 & 399.98 & 0.1123 & 67.4 \\
\hline MP57 days & 357.22 & 573.58 & 0.1268 & 583.19 & 347.61 & 0.1084 & 68.6 \\
\hline ADMP & 291.85 & 607.37 & 0.0237 & 603.17 & 296.05 & 0.0321 & 64.3 \\
\hline
\end{tabular}

$\mathrm{n}$ - number of animals; CV - coefficient of variation; ADMP - average daily milk production; Pr>F: probability of significance. 
by Ortiz et al. (2005), who worked with increasing levels of creep feeding and reported average gains of $410 \mathrm{~g}$ /day.

Lambs nursed by ewes from the 2.4 Mcal ME/kg DM group showed a daily gain difference of $160 \mathrm{~g}$ in relation to lambs from the severe restriction group and of $70 \mathrm{~g}$ in relation to the moderate restriction group. This difference is certainly related to the respective milk production of each group of ewes.

Lambs performance in terms of weight gain presented a positive correlation $(\mathrm{r}=0.60 ; \mathrm{P}<0.05)$ with birth weight, confirming the importance of this characteristic, emphasized by Silva Sobrinho (2001) and Geraseev (2006), for the development of the offspring. Lamb average daily weight gain also presented a positive correlation $(\mathrm{r}=0.41$; $\mathrm{P}<0.05)$ with the score of ewes at lambing, showing that the mother body condition at lambing can determine the growth rate of the lamb.

Twin lambs presented higher weights than single lambs for most of the weighing by the fact that their weights were added, i.e., calculations were done based on the lamb(s) weight per ewe (Table 11). Although there was no difference $(\mathrm{P}>0.05)$ in the average gain for single and twin lambs, ewes that lambed and raised twins, weaned an average of $4.840 \mathrm{~kg}$ of lamb more than ewes with a single lamb only, thus presenting greater productive efficiency at weaning.
Lamb genetic group had no influence on their weights (Table 11); however, lambs from wool ewes had a gain of $0.788 \mathrm{~kg} / \mathrm{L}$ of milk produced, while those from hair ewes gained only $0.346 \mathrm{~kg} / \mathrm{L}$ of milk. This led to the conclusion that lambs from wool ewes were more efficient at milk utilization, possibly due to heterosis.

The death of one lamb from the 2.2 Mcal ME/kg DM group was recorded until weaning, i.e., $5 \%$ of the lambs from ewes subjected to moderate energy restriction. As for the animals from the 2.0 level, the death of three lambs was recorded until weaning. This value represents $23 \%$ of the animals born from ewes from the severe restriction group, considering that $66 \%$ of these deaths occurred up to 72 hours after lambing. This result confirms the findings of Figueiró \& Benavides (1990), which show that an inadequate nutritional level during the last third of the gestational period incurs in higher neonatal mortality rates.

There were no deaths in the group that was fed with the 2.4 Mcal ME/kg DM diet. According to Villas Boas (1990), a well-managed herd presents mortality rates from birth to weaning of up to $9 \%$. According to him, these rates would be from 9 to $20 \%$ for a medium level herd management, and rates over $20 \%$ would identify badlymanaged herds.

Table 10 - Lambs average weight (in kg) at birth (LWB), at 14 (LW14), 28 (LW28), 42 (LW42), 56 (LW56) days, at weaning (LWW) and average daily gain (LADG) for the different energy levels

\begin{tabular}{|c|c|c|c|c|c|c|}
\hline \multirow[t]{2}{*}{ Variable } & \multicolumn{3}{|c|}{ Level of metabolizable energy (Mcal $/ \mathrm{kg}$ of $\mathrm{DM}$ ) } & \multirow[b]{2}{*}{ Regression } & \multirow[b]{2}{*}{$\mathrm{R}^{2}$} & \multirow[b]{2}{*}{ CV (\%) } \\
\hline & $2.4(\mathrm{n}=11)$ & $2.2(\mathrm{n}=10)$ & $2.0(n=9)$ & & & \\
\hline LWB & 5.79 & 6.05 & 4.68 & $\hat{y}=3.332 x-2.065$ & 0.11 & 30.3 \\
\hline LW 28 & 13.44 & 11.96 & 9.16 & $\hat{y}=11.282 x-13.583$ & 0.31 & 24.7 \\
\hline LW 42 & 17.35 & 14.98 & 10.67 & $\hat{y}=17.336 x-24.159$ & 0.44 & 23.3 \\
\hline LADG & 0.30 & 0.23 & 0.14 & $\hat{\mathrm{y}}=0.413 \mathrm{x}-0.692$ & 0.46 & 33.9 \\
\hline
\end{tabular}

DM - dry matter; $\mathrm{n}$ - number of observations; $\mathrm{R}^{2}$ - coefficient of determination; CV - coefficient of variation.

Table 11 - Lamb average weight (in kg) at birth (LWB), at 14 (LW14), 28 (LW28), 42 (LW42), 56 (LW56) days, at weaning (LWW) and average daily weight gain (LADG) for genetic group and type of lambing

\begin{tabular}{|c|c|c|c|c|c|c|c|}
\hline & \multicolumn{2}{|c|}{ Genetic group } & \multirow[b]{2}{*}{$\operatorname{Pr}>F$} & \multicolumn{2}{|c|}{ Type of lambing } & \multirow[b]{2}{*}{$\operatorname{Pr}>F$} & \multirow[b]{2}{*}{ CV (\%) } \\
\hline & Wool $(\mathrm{n}=12)$ & Hair $(\mathrm{n}=18)$ & & Single $(n=19)$ & Twins $(\mathrm{n}=11)$ & & \\
\hline LWB & 5.16 & 5.85 & 0.0748 & 4.38 & 6.64 & $<0.0001$ & 18.5 \\
\hline L W 14 & 8.20 & 8.97 & 0.2993 & 7.53 & 9.64 & 0.0089 & 22.6 \\
\hline L W 28 & 11.41 & 11.63 & 0.8248 & 10.40 & 12.64 & 0.0432 & 23.6 \\
\hline LW 42 & 14.46 & 14.21 & 0.8369 & 13.13 & 15.54 & 0.0644 & 22.4 \\
\hline LW56 & 17.67 & 16.87 & 0.6330 & 15.75 & 18.80 & 0.0880 & 25.7 \\
\hline L WW & 21.53 & 20.77 & 0.7429 & 18.73 & 23.57 & 0.0490 & 28.8 \\
\hline LADG & 0.23 & 0.21 & 0.4792 & 0.21 & 0.24 & 0.2241 & 34.2 \\
\hline
\end{tabular}

$\mathrm{n}$ - number of observations; CV - coefficient of variation; $\mathrm{Pr}>\mathrm{F}$ : probability of significance.

Note: The sum of the twin lambs weight was considered for the twin type of lambing. 


\section{Conclusions}

Ewe energy restriction at the end of the gestational period and during lactation limits ewe and lamb performance until weaning. Only the highest energy level led to good weight and body condition of ewes at weaning, allowing them to immediately enter a new breeding season, while their lambs showed weights close to the ideal for slaughtering. Pre and postnatal energy restriction of ewes increases lambs mortality rate until weaning, especially neonatal mortality.

\section{Acknowledgements}

The authors wish to thank CNPq (National Council for Scientific and Technological Development) for granting research productivity scholarships to Ribeiro and Mizubuti.

\section{References}

AVENDAÑO, R.J.; IMBARACH, A.J. Efecto de la suplementación durante el periparto sobre algunos parámetros productivos y reproductivos de la oveja Suffolk-Down y su cordero en el secano interior de la provincia de Cauquenes. Agricultura Técnica, v.62, n.1, p.110-120, 2002.

BOUCINHAS, C.C.; SIQUEIRA, E.R.; MAESTÁ, S.A. Dinâmica do peso e da condição corporal e eficiência reprodutiva de ovelhas da raça Santa Inês e mestiças Santa Inês-Suffolk submetidas a dois sistemas de alimentação em intervalos entre partos de oito meses. Ciência Rural, v.36, n.3, p.904-909, 2006.

CALDEIRA, R.M.; VAZ PORTUGAL, A. Condição corporal: conceitos, métodos de avaliação e interesse da sua utilização como indicador na exploração de ovinos. Revista Portuguesa de Ciências Veterinárias, v.93, n.526, p.95-102, 1998.

CAMPOS, J. Tabelas para cálculo de rações. 2.ed. Viçosa, MG: UFV, 1995. 64p.

CARDELLINO, R.A.; BENSON, M.E. Lactation curves of commercial ewes rearing lambs. Journal of Animal Science, v.80, n.1, p.23-27, 2002.

CARVALHO, S.; PIRES, C.C.; PERES, J.R.R. et al. Desempenho de cordeiros machos inteiros, machos castrados e fêmeas, alimentados em confinamento. Ciência Rural, v.29, n.1, p.129-133, 1999.

FIGUEIRÓ, P.R.P.; BENAVIDES, M.V. Produção de carne ovina. In: Sociedade Brasileira de Zootecnia (Ed.) Caprinocultura e ovinocultura. Piracicaba: FEALQ, 1990. p.15-31.

GERASEEV, L.C.; PEREZ, J.R.O.; CARVALHO, P.A. et al. Efeitos das restrições pré e pós-natal sobre o crescimento e o desempenho de cordeiros Santa Inês do nascimento ao desmame. Revista Brasileira de Zootecnia, v.35, n.1, p.245-251, 2006.

GODFREY, R.W.; DODSON, R.E. Effect of suplemental nutrition around lambing on hair sheep lambs and lambs during the dry and wet seasons in the U.S. Virginia Islands. Journal of Animal Science, v.81, p.587-593, 2003.

HOFFMANN, R.P. Diagnóstico de parasitismo veterinário. Porto Alegre: Sulina, 1987. 156p.

KEARL, L.C. Nutrient requirements of ruminants in developing countries. Logan: International Feedstuffs Institute, Utah Agricultural Experiment Station, Utah State University, 1982. 381p.
MAACK, R. Geografia física do Estado do Paraná. 2.ed. Rio de Janeiro: José Olympio, 1981. 450p.

MELLOR, D.J. Nutritional effects on the fetus and mammary gland during pregnancy. Proceedings of the Nutrition Society, v.46, p.249-257, 1987

MINOLA, J.; GOYENECHEA, J. Praderas \& lanares: producción ovina en alto nivel. Montevideo: Hemisferio Sur, [S.d.]. 365p

MOURA FILHO, J; RIBEIRO, E.L.A.; SILVA, L.D.F. et al. Suplementação alimentar de ovelhas no terço final de gestação: desempenho de ovelhas e cordeiros até o desmame. Semina. Ciências Agrárias, v.26, n.2, p.257-266, 2005.

NATIONAL RESEARCH COUNCIL - NRC. Nutrient requirements of sheep. 6.ed. Washington, D.C.: National Academy Press, 1985. 112p.

NATIONAL RESEARCH COUNCIL - NRC. Nutrient requirements of small ruminants: sheep, goats, cervids and new camelids. Washington, D.C.: National Academy Press, 2007. 384p.

ORTIZ, J.S.; COSTA, C.; GARCIA, C.A. et al. Efeito de diferentes níveis de proteína bruta na ração sobre o desempenho e as características de carcaça de cordeiros terminados em creep feeding. Revista Brasileira de Zootecnia, v.34, n.6, p.23902398, 2005.

OSÓRIO, J.C.S.; OSÓRIO, M.T.M. Produção de carne ovina: técnicas de avaliação "in vivo" e na carcaça. 2.ed. Pelotas: Ed. Universitária, UFPEL, 2005. 82p.

PODLESKIS, M.R.; RIBEIRO, E.L.A.; ROCHA, M.A. et al. Produção de leite de ovelhas Hampshire Down e Ile de France até os 84 dias de lactação. Semina Ciências Agrárias, v.26, n.1, p.117-124, 2005.

RAMSEY, W.S.; HATFIELD, P.G.; WALLACE, J.D. Relationships among lamb milk production and lamb and lamb forage intake in Suffolk and Targhee lambs nursing single and twin lambs. Journal of Animal Science, v.76, n.4, p.1247-1253, 1998.

RIBEIRO, L.C.; PEREZ, J.R.O.; CARVALHO, P.H.A. et al. Produção, composição e rendimento em queijo do leite de ovelhas Santa Inês tratadas com ocitocina. Revista Brasileira de Zootecnia, v.36, n.2, p.438-444, 2007.

SCHEAFFER, A.N.; CATTON, J.S.; REDMER, D.A. et al. The effect of dietary restriction, pregnancy and fetal type in different lamb types on fetal weight, maternal body weight and visceral organ mass in lambs. Journal of Animal Science, v.82, p.1826-1838, 2004.

SIBBALD, A.M.; DAVIDSON, G.C. The effect of nutrition during early life on voluntary food intake by lambs between weaning and 2 years age. Animal Science, v.66, p.697-703, 1998.

SILVA, D.J.; QUEIROZ, A.C. Análise de alimentos: métodos químicos e biológicos. 3.ed. Viçosa, MG: UFV, 2002. 235p.

SILVA SOBRINHO, A.G. Criação de ovinos. 2.ed. Jaboticabal: Funep, 2001. 302p.

SILVEIRA, V.C.P.; LOPEZ, J.; RODRIGUES, F.E. Influência da nutrição materna e do sexo na reserva energética do cordeiro ao nascer. Revista da Sociedade Brasileira de Zootecnia, v.12, n.2, p.242-249, 1992.

SNOWDER, G.D.; GLIMP, H.A. Influence of breed, number of suckling lambs, and stage of lactation on lamb milk production and lamb growth under range conditions. Journal of Animal Science, v.69, n.3, p.923-930, 1991.

SOUZA, C.J.H.; SILVEIRA, V.C.P.; MORAES, J.C.F. Suplementação energética de ovelhas na última semana pré-parto aumenta a sobrevivência de cordeiros. Bagé: EMBRAPA, 2009. 5p (Circular Técnica, 37).

SUSIN, I. Exigências nutricionais de ovinos e estratégias de alimentação. In: SILVA SOBRINHO, A.G.; BATISTA, A.M.V.; SIQUEIRA, E.R. (Eds.) Nutrição de ovinos. Jaboticabal: Funep, 1996. p.119-141.

VILLAS BOAS, A.S. Instalações e manejo do rebanho ovino. In: SILVA SOBRINHO, A.G. (Ed.) Produção de ovinos. Jaboticabal: Funep, 1990. p.27-63. 